\title{
The effectiveness of the preliminary games program on the Level performance of some basic skills and Special motor Abilities in wrestling sport
} Dr / Emad Sabry Saleep Saad

\section{Introduction and research problem:}

The basic skills in the sport of wrestling are those movements that a wrestler must practice to succeed in this sport, and to improve the level of wrestlers coaches must add exercise which is develop the basic skills in preparation programs.

The preliminary games considered a ways to acquire motor skills, through which it learner acquires skills faster and more interesting and understanding, as the preliminary games seek to achieve many of the educational goals due to distinguish multiple and disparate attitudes when they are used, when practice bud is gaining motor abilities properly with stages of growth and individual characteristics. (11: 1)

\section{Deeniss and Johnson} (1991) training programs intended for secondary stages equipped with games related to wrestling interference fun atmosphere, where such activities are used in sophistication sport. (21: 159)

Whereas the preliminary games will be in the form of grainy competitions for players with a tool or without a tool aimed at providing the motor skills of the different games in addition to development the physical components (8: 2630)

These Games contribute to Acquisition of physical qualities, its laws and the rules simple and clear and not subject to international laws, and for different ages, and characterized by fun and pleasure and excitement for members. (3: 35-36)

Ali rehaan (2006) refer to that the basic skills training helps to raise the standard of the conflict from the top, it is also used to teach the technique wrestling and training, and is also used to improve the physical abilities and functional and technical capabilities of the wrestlers, but the importance of these skills must be trained on the 
attention and continuous training them. (4:308)

Also before start to learn the special skills we need to give wrestlers basic concept about the basics of wrestling. (20:83)

However, the researcher has observed through the expertise in the field of training and teaching, that the difficulties faced by beginners when practicing wrestling and learning basic skills specially lifting up and arching skill more difficult skills facing the students of the first grade at the faculty of physical education for boys , zagazig university, when actual wrestling practice, where it is sufficient to perform some simple exercise to learn basic skills quickly and move on to start learning the actual wrestling skills by making sure they maintained the basic motor skills that help them and qualify them to practice wrestling proper and correct, here Mossad ali mahmoud refers to (2003) wrestler who can integrate the lifting up and arching skills to become distinguished players in wrestling. ( 17 $: 14$ )

Also, Mohammad Reda Hafez Roby refers to (2007) the bridge skill of the basic skills in the wrestling sport, It is the basic stone of most wrestling movements, wrestler who have strong bridge can implement most of the attack and defensive movements as effectively, as he can avoid touching shoulders and avoid defeat and convert defeat to win the match. (15: 239)

Mohammed Jaber , Ihab Badawi (2002) the lifting up skill is essential for all wrestling techniques, he used in the implementation of throws and put the opponent on the shoulders, and to escape and counter-attack, and the registration of additional points to some types of lifting. (13: 73), and also the arching skill is one of the difficult learning skills, and open the way for more exciting throws in wrestling. (13:89). which explains the importance of each the lifting up and arching skills for wrestlers as the most important basic skills.

From here came the idea of research to find solutions for this problem by designing educational program contains some preliminary games that contribute to acquire the simple research all of lifting up and arching skills, and some special motor abilities for this 
stage, and researcher hopes that represents this research adding new in the field of education and training for wrestling in the Arab Republic of Egypt.

Aim of the research: The research aims to design a proposed educational program by using the preliminary games to know:

1 - The effect of the proposed program on the level of some Special motor Abilities to the research sample.

2 - The effect of the proposed educational program on the performance level of lifting up and arching skills to the research sample.

3. The significance of differences between the two groups experimental and control at the level of some Special motor abilities and the level of performance skills.

Research hypotheses: 1There are statistically significant differences between the averages of pre and after measurements to the experimental group and the control group in some Special motor Abilities and in favor of the after measurement.

2 - There are statistically significant differences between the averages of after measurements for the experimental and control groups in the level of some special motor abilities and in favor the experimental group.

3. There are statistically significant differences between the averages of after measurements for the experimental and control groups in the level performance of lifting up and arching skills and in favor of the experimental group.

\section{The plan and the procedures} of the Research:

\section{Research procedures:}

The researcher used the experimental methodology using a pre- measurements and after measurements of two group (experimental and control group).

The research sample: The sample was chosen with random way from the students of the first grade at the Faculty of Physical Education for Boys zagazig University, for the academic year 2014 / 2015 and the number of the sample (48) student, was selected students for survey study to become a number of sample (40) students were divided randomly into two groups experimental and control, and the number of each of them (20) students in both groups.

\section{Assiut Journal For Sport Science Arts}


Table (1)

Statistical characterization of the sample research in growth variables $n=48$

\begin{tabular}{c|c|c|c|c|c|c}
\hline \hline Sr. & $\begin{array}{c}\text { The } \\
\text { variables }\end{array}$ & $\begin{array}{c}\text { Unit of } \\
\text { measuring }\end{array}$ & mean & Deviation & Median & skewness \\
\hline \hline 1 & age & Year & 18.33 & 0.30 & 18.35 & -0.21 \\
\hline 2 & weight & $\mathrm{Kg}$ & 70.00 & 2.23 & 69.50 & 0.65 \\
\hline 3 & Tallness & $\mathrm{Cm}$ & 177.00 & 2.08 & 176.50 & 0.72 \\
\hline \hline
\end{tabular}

Table (1 ) that the skewness values are limited between

(0.21: 0.72) and all values

Table (2).

between \pm 3 , which refers to the homogeneity of the research sample.

Statistical characterization of the sample research in some motor abilities $n=48$

\begin{tabular}{c|c|c|c|c|c|c}
\hline \hline Sr. & $\begin{array}{c}\text { The } \\
\text { variables }\end{array}$ & $\begin{array}{c}\text { Unit of } \\
\text { measuring }\end{array}$ & mean & Deviation & Median & skewness \\
\hline \hline 1 & $\begin{array}{c}\text { Leg } \\
\text { strength }\end{array}$ & $\mathrm{Kg}$ & 104.85 & 5.66 & 105.50 & -0.34 \\
\hline 2 & $\begin{array}{c}\text { back } \\
\text { muscles } \\
\text { Strength }\end{array}$ & $\mathrm{Kg}$ & 91.69 & 4.62 & 92.50 & -0.53 \\
\hline 3 & $\begin{array}{c}\text { Board } \\
\text { jump }\end{array}$ & $\mathrm{Cm}$ & 211.92 & 18.30 & 217.50 & -0.92 \\
\hline 4 & $\begin{array}{c}\text { Pay } \\
\text { medical } \\
\text { football }\end{array}$ & $\mathrm{M}$ & 7.43 & 0.35 & 7.35 & 0.68 \\
\hline 5 & Horizontal & $\mathrm{Cm}$ & 39.29 & 4.04 & 40.00 & -0.53 \\
\hline 6 & $\begin{array}{c}\text { A vertical } \\
\text { flexibility }\end{array}$ & $\mathrm{Cm}$ & 44.06 & 3.93 & 44.00 & 0.05 \\
\hline 7 & Agility & Number & 5.35 & 0.67 & 5.00 & 1.59 \\
\hline \hline
\end{tabular}

Table (3) that the skewness values are limited between (0.92: 1.59) and all values between \pm 3 , Which refers to the homogeneity of the research sample. 
Table(3)

Valence between the control and experimental groups in the growth variables $n 1=n 2=20$

\begin{tabular}{|c|c|c|c|c|c|c|c|}
\hline \multirow[t]{2}{*}{ Sr. } & \multirow[t]{2}{*}{$\begin{array}{c}\text { The } \\
\text { variables }\end{array}$} & \multirow[t]{2}{*}{$\begin{array}{c}\text { Unit of } \\
\text { measuring }\end{array}$} & \multicolumn{2}{|c|}{ Control group } & \multicolumn{2}{|c|}{$\begin{array}{l}\text { Experimental } \\
\text { group }\end{array}$} & \multirow[t]{2}{*}{$\begin{array}{c}T \\
\text { value }\end{array}$} \\
\hline & & & mean & Deviation & mean & Deviation & \\
\hline$T$ & age & year & $11 . \Gamma \xi$ & $\cdot$ TO $^{\prime}$ & $1 \Lambda . \mu \nu$ & - YY & 0.40 \\
\hline$r$ & weight & $\mathrm{Kg}$ & 79.8. & T.RT & $V . .10$ & $T . \leqslant 7$ & 0.60 \\
\hline$r$ & Tallness & $\mathrm{Cm}$ & IVV.TO & r.II & 187.70 & $r .9$ & 1.06 \\
\hline
\end{tabular}

* The table value of $\mathrm{T}$. at the level of significance $0.05=2.02$

table (3) shows that there are no differences with a statistical significance between the experimental and control
Table (4)

groups in the pre -measurement of growth variables, This refers to the valence of between the two groups.

Valence between the control and experimental groups in some motor abilities $\mathbf{n} 1=\mathbf{n} 2=\mathbf{2 0}$

\begin{tabular}{|c|c|c|c|c|c|c|c|}
\hline \multirow[t]{2}{*}{ Sr. } & \multirow{2}{*}{$\begin{array}{c}\text { The } \\
\text { variables }\end{array}$} & \multirow{2}{*}{$\begin{array}{c}\text { Unit of } \\
\text { measuring }\end{array}$} & \multicolumn{2}{|c|}{ Control group } & \multicolumn{2}{|c|}{$\begin{array}{c}\text { Experimental } \\
\text { group }\end{array}$} & \multirow{2}{*}{$\begin{array}{c}\mathbf{T} \\
\text { value }\end{array}$} \\
\hline & & & Mean & Deviation & mean & Deviation & \\
\hline 1 & $\begin{array}{c}\text { Leg } \\
\text { strength }\end{array}$ & $\mathrm{Kg}$ & o. & $7 . V$ & $1 . \leqslant .10$ & $0.1 T$ & $\because \vee \wedge$ \\
\hline r & $\begin{array}{l}\text { back } \\
\text { muscles } \\
\text { Strength }\end{array}$ & $\mathrm{Kg}$ & $9 \cdot .70$ & $\varepsilon .1 V$ & qr. ro & $\varepsilon .94$ & 1.11 \\
\hline r & $\begin{array}{l}\text { Board } \\
\text { jump }\end{array}$ & $\mathrm{Cm}$ & YI. & זמיזו & 5.9 .10 & $r \varepsilon .0$ & . \\
\hline$\varepsilon$ & $\begin{array}{l}\text { Pay } \\
\text { medical } \\
\text { football }\end{array}$ & M & V.r & $\cdot r$. & V.OT & $\cdot r v$ & I.VY \\
\hline 0 & Horizontal & $\mathrm{Cm}$ & $\varepsilon \cdot . \varepsilon \cdot$ & $\varepsilon . Y A$ & rᄉ.. 0 & $\varepsilon . V$ & I.VA \\
\hline 7 & $\begin{array}{l}\text { A vertical } \\
\text { flexibility }\end{array}$ & $\mathrm{Cm}$ & $\varepsilon \varepsilon .0$ & 5.19 & $\varepsilon \varepsilon .7$. & r.7. &.$\leq 0$ \\
\hline v & Agility & Number & $0 . r_{0}$ & $.7 \varepsilon$ & 0 &. Vo &.$\leqslant 7$ \\
\hline
\end{tabular}

The table value of $\mathrm{T}$. at the level of significance $0.05=2.02$

Table (4) shows that statistical significance between there are no differences with a the experimental and control Assiut Journal For Sport Science Arts 
groups in the pre -measurement of some motor abilities, This refers to the valence of between the two groups .

\section{Tests}

- Test of the maximum power of the legs. . Test of the maximum power of the back. - Test of the ability of muscles. (legs \& hands) - Test of agility - Test of flexibility. - Test of level performance of skills.

Assessment the level performance of the basic skills: It was filmed the basic skills of the sample research using a digital video camera, the first time in the premeasurements and the second time in after measurements, was then display on the three Referees to assessment the technical performance level of the skills, so it gave 10 marks for each skill for assessment.

Sobhy Hassanein refer to (1995) that the subjective evaluation is a kind of evaluation, which does not depend on the standards and levels but depends on the expertise of referees, and so the subjective evaluation uses in many sporting activities. (16:42)

\section{Luttgens\&}

Hamilto (1997) we judge the effectiveness of the performance by the success or failure to achieve its objectives. (24: 2$)$

The proposed program of preliminary games:

The goal of the training program: Identify the effect of the preliminary games on performance Level of some basic skills and Special motor Abilities for the students of the first grade at the Faculty of Physical Education for Boys Zigzag University

The proposed program: The program contains a set of preliminary games, and characterized by the excitement, competition and fun to raise the motivation of students to actual practice.

follows:- preliminary games for lifting skill. - Preliminary games for arching skill.

The following forms: (Individual performance performance with a colleague performing in groups performance tools).

Timespan of the program: It has been identified time period for the proposed program by the duration of (8) weeks, (2) teaching units a week, and a total units is (16) educational units.

Module time: Module time duration of 60 minutes (the time of the lecture) divided 
parts of the unit, according to the time of the module within the college. Components of Unit: • Primer part includes a warmup and physical preparation ranges time from $10 \mathrm{~m}: 15 \mathrm{~m}$.

- main part includes the educational part ranges time from $40 \mathrm{~m}$ : $45 \mathrm{~m}$.

- Finished part includes the exercise calm and relaxed and his time of $5 \mathrm{~m}$.

Study of basic research:
The researcher conducting the pre- measurement on day 2 / 10 / 2014, and the proposed program (basic study) on experimental research sample in the period from $4 / 10 / 2014$ to $29 / 10 / 2014$ at zagazig university Stadium, for (8) weeks rate of (2) units per week, and application the traditional program on the control group, The researcher conducting the after measurement on day $30 / 11 / 2014$.

table (5)

Significance of differences between pre and after measurement in some motor abilities of the experimental group $n=20$

\begin{tabular}{|c|c|c|c|c|c|c|c|}
\hline \multirow[t]{2}{*}{ Sr. } & \multirow{2}{*}{$\begin{array}{c}\text { The } \\
\text { variables }\end{array}$} & \multirow{2}{*}{$\begin{array}{c}\text { Unit of } \\
\text { measuring }\end{array}$} & \multicolumn{2}{|c|}{ measurement pre } & \multicolumn{2}{|c|}{$\begin{array}{c}\text { After } \\
\text { measurement }\end{array}$} & \multirow{2}{*}{$\begin{array}{c}\mathrm{T} \\
\text { value }\end{array}$} \\
\hline & & & mean & Deviation & mean & Deviation & \\
\hline 1 & $\begin{array}{c}\text { Leg } \\
\text { strength }\end{array}$ & $\mathrm{Kg}$ & 104.15 & 5.12 & 116.00 & 3.54 & $14.89 *$ \\
\hline$r$ & $\begin{array}{c}\text { back } \\
\text { muscles } \\
\text { Strength }\end{array}$ & $\mathrm{Kg}$ & 92.25 & 4.93 & 107.45 & 6.39 & $13.29 *$ \\
\hline$r$ & $\begin{array}{l}\text { Board } \\
\text { jump }\end{array}$ & $\mathrm{Cm}$ & 209.15 & 24.05 & 230.20 & 8.61 & $4.25^{*}$ \\
\hline$\varepsilon$ & $\begin{array}{c}\text { Pay } \\
\text { medical } \\
\text { football }\end{array}$ & $\mathrm{M}$ & 7.52 & 0.37 & 8.16 & 0.33 & $15.29 *$ \\
\hline 0 & Horizontal & $\mathrm{Cm}$ & 38.05 & 4.07 & 32.65 & 3.98 & $25.68^{*}$ \\
\hline 7 & $\begin{array}{l}\text { A vertical } \\
\text { flexibility }\end{array}$ & $\mathrm{Cm}$ & 44.60 & 3.60 & 48.55 & 2.99 & $13.41^{*}$ \\
\hline V & Agility & Number & 5.35 & 0.75 & 6.50 & 0.95 & $8.76 *$ \\
\hline
\end{tabular}

The table value of $\mathrm{T}$. at the level of significance $0.05=2.02$ Assiut Journal For Sport Science Arts 
table (5) There are significant differences between pre and after measurement in some motor abilities of the experimental group for after measurement.

Table (6)

Significance of differences of level performance for the experimental group $\mathbf{n}=\mathbf{2 0}$

\begin{tabular}{|c|c|c|c|c|c|c|}
\hline \multirow[t]{2}{*}{ Sr. } & \multirow{2}{*}{$\begin{array}{c}\text { The } \\
\text { variables }\end{array}$} & \multicolumn{2}{|c|}{$\begin{array}{c}\text { level of } \\
\text { performance }\end{array}$} & \multirow{2}{*}{$\begin{array}{l}\text { Degree } \\
\text { of } \\
\text { freedom }\end{array}$} & \multirow{2}{*}{$\begin{array}{c}\mathbf{T} \\
\text { value }\end{array}$} & \multirow{2}{*}{$\begin{array}{c}\text { Probability } \\
\text { Sig.(p.value) }\end{array}$} \\
\hline & & mean & Deviation & & & \\
\hline 1 & $\begin{array}{l}\text { Lifting } \\
\text { up skill }\end{array}$ & 1.10 &.$T V$ & 19 & سח.ץו & .1 \\
\hline$r$ & Arching skill & $\vee . \wedge 0$ & .09 & 19 & $17 . \mathrm{r}$ & $\because \cdot 1$ \\
\hline
\end{tabular}

Significance of differences when Sig. (P.value) $<0.05$

table (6)shows that the (p.Value) to 0.01 of a level of performance skills for the experimental group which is lower than the level of significance 0.05 ), There are
Statistical significance for pre after measurement in some motor abilities of the experimental group when compared with the maximum limit of 10 marks.

table (7)

Significance of differences between pre and after measurement in some motor abilities of the control group $n=2$

\begin{tabular}{c|c|c|c|c|c|c|c}
\hline \hline \multirow{2}{*}{ Sr. } & \multirow{2}{*}{$\begin{array}{c}\text { The } \\
\text { variables }\end{array}$} & \multirow{2}{*}{$\begin{array}{c}\text { Unit of } \\
\text { measuring }\end{array}$} & \multicolumn{2}{|c|}{ measurement pre } & \multicolumn{2}{|c|}{$\begin{array}{c}\text { After } \\
\text { measurement }\end{array}$} & \multirow{2}{*}{$\begin{array}{c}\text { T } \\
\text { value }\end{array}$} \\
\cline { 5 - 8 } & & mean & Deviation & mean & Deviation & \\
\hline \hline$r$ & $\begin{array}{c}\text { Leg } \\
\text { strength }\end{array}$ & $\mathrm{Kg}$ & 105.35 & 6.07 & 110.90 & 6.88 & $4.68^{*}$ \\
\hline$r$ & $\begin{array}{c}\text { back muscles } \\
\text { Strength }\end{array}$ & $\mathrm{Kg}$ & 90.65 & 4.17 & 96.30 & 5.47 & $4.64^{*}$ \\
\hline$r$ & Board jump & $\mathrm{Cm}$ & 211.40 & 13.32 & 219.45 & 10.16 & $4.19^{*}$ \\
\hline$\varepsilon$ & $\begin{array}{c}\text { Pay medical } \\
\text { football }\end{array}$ & $\mathrm{M}$ & 7.34 & 0.30 & 7.48 & 0.29 & $3.40^{*}$ \\
\hline$\bullet$ & Horizontal & $\mathrm{Cm}$ & 40.40 & 4.28 & 36.25 & 4.29 & $14.18^{*}$ \\
\hline$r$ & $\begin{array}{c}\text { A vertical } \\
\text { flexibility }\end{array}$ & $\mathrm{Cm}$ & 44.05 & 4.19 & 47.00 & 3.68 & $9.21^{*}$ \\
\hline$\vee$ & Agility & Number & 5.25 & 0.64 & 5.80 & 0.52 & $4.82^{*}$ \\
\hline \hline
\end{tabular}

The table value of $\mathrm{T}$. at the level of significance $0.05=2.02$ 
table (7) There are significant differences between pre and after measurement in some motor abilities of the control group for after measurement

Table (8)

Significance of differences of level of performance for the control group $\mathbf{n}=\mathbf{2 0}$

\begin{tabular}{c|c|c|c|c|c|c}
\hline \hline \multirow{2}{*}{ Sr. } & \multirow{2}{*}{ The variables } & \multicolumn{2}{|c|}{ level of performance } & \begin{tabular}{c} 
Degree \\
of \\
\cline { 3 - 5 }
\end{tabular} & $\begin{array}{c}\text { T } \\
\text { freedom }\end{array}$ & $\begin{array}{c}\text { Probabilue } \\
\text { Sig.(p.value) }\end{array}$ \\
\cline { 3 - 6 }$r$ & $\begin{array}{c}\text { Lifting up } \\
\text { skill }\end{array}$ & 7.05 &. .79 & 19 & 19.22 & 0.01 \\
\hline$r$ & Arching skill & 6.35 &..$\Sigma 9$ & 19 & 33.36 & 0.01 \\
\hline \hline
\end{tabular}

Significance of differences when Sig. (P.value) $<0.05$

table (8)shows that the (p.Value) to 0.01 of a level of performance skills for the experimental group which is lower than the level of significance 0.05 ), There are

Table (9)

Significance of differences between control and experimental groups in some motor abilities $n 1=n 2=20$

\begin{tabular}{|c|c|c|c|c|c|c|c|}
\hline \multirow{2}{*}{ Sr. } & \multirow{2}{*}{$\begin{array}{c}\text { The } \\
\text { variables }\end{array}$} & \multirow{2}{*}{$\begin{array}{c}\text { Unit of } \\
\text { measuring }\end{array}$} & \multicolumn{2}{|c|}{ Control group } & \multicolumn{2}{|c|}{$\begin{array}{l}\text { experimental } \\
\text { group }\end{array}$} & \multirow{2}{*}{$\begin{array}{c}\mathbf{T} \\
\text { value }\end{array}$} \\
\hline & & & mean & Deviation & mean & Deviation & \\
\hline$\overline{1}$ & Leg strength & $\overline{\mathrm{Kg}}$ & 110.90 & 6.88 & 116.00 & 3.54 & $2.95 *$ \\
\hline$r$ & $\begin{array}{c}\text { back muscles } \\
\text { Strength }\end{array}$ & $\mathrm{Kg}$ & 96.30 & 5.47 & 107.45 & 6.39 & $5.93 *$ \\
\hline$\Gamma$ & Board jump & $\mathrm{Cm}$ & 219.45 & 10.16 & 230.20 & 8.61 & $3.61 *$ \\
\hline$\varepsilon$ & $\begin{array}{l}\text { Pay medical } \\
\text { football }\end{array}$ & M & 7.48 & 0.29 & 8.16 & 0.33 & $6.85^{*}$ \\
\hline 0 & Horizontal & $\mathrm{Cm}$ & 36.25 & 4.29 & 32.65 & 3.98 & $2.75 *$ \\
\hline 7 & $\begin{array}{l}\text { A vertical } \\
\text { flexibility }\end{array}$ & $\mathrm{Cm}$ & 47.00 & 3.68 & 48.55 & 2.99 & 1.46 \\
\hline v & Agility & Number & 5.80 & 0.52 & 6.50 & 0.95 & $2.90 *$ \\
\hline
\end{tabular}

The table value of $T$. at the level of significance $0.05=2.02$

Assiut Journal For Sport Science Arts 
table (9) there are statistically significant difference between the control group and the

Table (10)

experimental groups in favor of the experimental group in physical variables.

Significance of differences between control and experimental groups in the level of Performance skills n1=n2=20

\begin{tabular}{c|c|c|c|c|c|c|c}
\hline \hline \multirow{2}{*}{ Sr. } & \multirow{2}{*}{$\begin{array}{c}\text { The } \\
\text { variables }\end{array}$} & \multirow{2}{*}{$\begin{array}{c}\text { Unit of } \\
\text { measuring }\end{array}$} & \multicolumn{2}{|c|}{ Control group } & \multicolumn{2}{|c|}{$\begin{array}{c}\text { experimental } \\
\text { group }\end{array}$} & \multirow{2}{*}{$\begin{array}{c}\text { T } \\
\text { value }\end{array}$} \\
\cline { 4 - 7 } & & mean & Deviation & mean & Deviation & \\
\hline \hline & $\begin{array}{c}\text { Lifting } \\
\text { up skill }\end{array}$ & marks & 7.05 & 0.69 & 8.15 & 0.67 & $5.13^{*}$ \\
\hline$r$ & $\begin{array}{c}\text { Arching } \\
\text { skill }\end{array}$ & marks & 6.35 & 0.49 & 7.85 & 0.59 & $8.78^{*}$ \\
\hline \hline
\end{tabular}

The table value of $\mathrm{T}$. at the level of significance $0.05=2.02$

table (10) there are group in favor of the statistically significant experimental group in the difference between the control level of performance skills group and the experimental

Table (11)

Percentage improvement in the in some motor abilities of the two groups (control group and the experimental group) $n 1=n 2=20$

\begin{tabular}{|c|c|c|c|c|c|c|c|}
\hline \multirow[b]{2}{*}{ Sr. } & \multirow{2}{*}{$\begin{array}{c}\text { The } \\
\text { variables }\end{array}$} & \multicolumn{2}{|c|}{ control group } & \multirow{2}{*}{$\begin{array}{c}\text { Percentage } \\
\text { improvement } \\
\%\end{array}$} & \multicolumn{2}{|c|}{$\begin{array}{c}\text { experimental } \\
\text { group }\end{array}$} & \multirow{2}{*}{$\begin{array}{c}\text { Percentage } \\
\text { improvement } \\
\%\end{array}$} \\
\hline & & $\begin{array}{l}\text { Mean } \\
\text { of pre }\end{array}$ & $\begin{array}{c}\text { Mean } \\
\text { of } \\
\text { after }\end{array}$ & & $\begin{array}{l}\text { Mean } \\
\text { of pre }\end{array}$ & $\begin{array}{c}\text { Mean } \\
\text { of } \\
\text { after }\end{array}$ & \\
\hline 1 & Leg strength & 105.35 & 110.90 & $\overline{5.27}$ & 104.15 & 114.90 & 11.38 \\
\hline 2 & $\begin{array}{c}\text { back } \\
\text { muscles } \\
\text { Strength }\end{array}$ & 90.65 & 96.30 & 6.23 & 92.25 & 105.60 & 16.48 \\
\hline 3 & $\begin{array}{l}\text { Board } \\
\text { jump }\end{array}$ & 211.40 & 219.45 & 3.81 & 209.15 & 230.20 & 10.06 \\
\hline 4 & $\begin{array}{l}\text { Pay medical } \\
\text { football }\end{array}$ & 7.34 & 7.48 & 1.94 & 7.52 & 8.16 & 8.44 \\
\hline 5 & Horizontal & 40.40 & 36.25 & 10.27 & 38.05 & 32.65 & 14.19 \\
\hline 6 & $\begin{array}{l}\text { A vertical } \\
\text { flexibility }\end{array}$ & 44.05 & 47.00 & 6.70 & 44.60 & 48.55 & 8.86 \\
\hline 7 & Agility & 5.25 & 5.80 & 10.48 & 5.35 & 6.50 & 21.50 \\
\hline
\end{tabular}


table (11) There are differences in the of improvement percentage between the two measurements pre and after for the experimental and control groups in the motor abilities and in favor of the experimental group.

Discussing the results:

Discussing the results of the first hypothesis:

Table $\left({ }^{0}\right)$ shows that there are differences statistical significance at the significance level (0.05) between the two measurements pre and after of experimental group in some motor abilities (leg strength, strength of the back muscles, muscle power, agility) in favor of aftert-measurement. Table (1) shows that some motor abilities have improved of experimental research sample.

The researcher attributed to the differences statistical significance, and percentage improvement with the experimental research sample in some motor abilities to the positive effect of the proposal program, which included a preliminary games in various forms (individual, couples, by tools), which led to provoke interest youth and push them into more of the effort, which reflected an improvement in some motor abilities.

Mohammad

Hassan

Allawi refer to (1999) (12) that The preliminary games are characterized by rich for aspects of motor learning and with good selected can be used for the development of some of the physical elements.

Byra (1988) (19) that the units of small games in physical and skill training programs have many positive benefits, where it can achieve many of the intended purposes.

This is previous results consistent with results of each of Mohammad Hamid Shaddad, Khalid Farid Izzat (2012) (11), Aml Hashim (2008) (5), Kazlovks (1981) (23) Where their findings pointed to the effectiveness and impact of to the various programs the preliminary games in development motor abilities.

Table (7) shows that there are differences statistical significance at the significance level (0.05) between the two measurements pre and after of control group in some motor abilities (leg strength, strength of the back muscles, muscle power, agility) in favor of 
after-measurement. table (11) shows that some motor abilities have improved of control research sample. The researcher attributed to the significance differences, and percentage improvement with the control group in some motor abilities to the educational program that has been applied to the control group, where the program contained a general physical exercises and the continuous and systematic within the educational program of training led to adaptation and the next process upgrading the level of motor abilities, here Adel Abdul Basir refer to (1999) (1) that The adaptation in the training and upgrading process that can only be done through constant and continuous training.

This is consistent with a study by Mohammed Hamid Shaddad, Khaled Fred Ezzat (2012) (11), Ahmad Badawi (2011) (2) where he pointed to that the program followed the control group lead to the improvement of the results of the after test measurements.

In this first hypothesis is achieved, which stipulates that "There are statistically significant differences between the averages of pre and after measurements to the experimental group and the control group in some Special motor Abilities and in favor of the after measurement"

Discuss the results of the second hypothesis:

Table (6) showing there are a statistical significance for after measurement in the level of performance skills (lifting up , arching) for the experimental group when compared to the maximum of 10 marks, as the value of (p.Value) calculated equal to 0.01 and is less than the level of value 0.05 . Table (8) showing there are a statistical significance for the after measurement in the level of performance skills (lifting up, arching) for the control group when compared to the maximum of 10 marks, as the value of ( $p$.Value) calculated equal to 0.01 and is less than the level of value 0.05 Table (10) showing there are statistical differences significance between the two after measurements for the control and experimental groups and in favor of the experimental group in the level of performance 
skills. The researcher

attributed to differences statistical significance at the level of performance skill of the experimental group for the control group to the proposed program for preliminary games and that has been applied to the experimental group which included a set of preliminary games are designed in conformity with the direction track of skills, and this is not available in the traditional program with the control group, and the proposed program included a variety of games used and the existence of the competition factor among the students when doing their preliminary games in addition to the enthusiasm and joy inside the unit, which has affected positively and effectively increase the motivation of students toward the learning process. And the researcher attributed to differences statistical significance and improvements in the level of performance skills (lifting up, arching) for the control group to the traditional program, which contained the drills and a similar performance contributed to the improved level performance of skill as a result of the continuity of training and practice of the program followed, which It contributed to the improved level of performance skills of the control group

Mohammed

Abdullah," 2006

Ahmed

preliminary development the individual performance of the skills of the various sporting activities, which increases the the motivation of the individual towards sports activities.

This is consistent with both of Anwar Khouly and Jamal al-Din Shafie (2009)( 6) that the novice does not want to learn the skills separately because it sends boredom, but they want to learn the skills inside groups because it gives the education fun and pleasure, so the preliminary games run on increase the motivation of the learner to learning as it reduces the traditional exercises and flexible .

Consistent with a study by Mohammed Shaddad, Khalid Izzat (2012) (11), Ahmad Badawi, "2011 (2), Rania Abdel Jawad" 2008 (18), Mohamed Noah " 2005 (14), where their findings pointed to improved level performance of the skill of the experimental 
group that used the preliminary games for the control group .

In this second hypothesis is achieved, which stipulates that There are statistically significant differences between the averages of after measurements for the experimental and control groups in the level of some special motor abilities and in favor the experimental group.

Discuss the results of the third hypothesis:

Table (9) showing There are significant differences between the average two after measurement for both groups (experimental -control) in the level of some motor abilities of a sample and in favor of the experimental group. table (11)shows that the experimental group had improved in all motor abilities for the control group.

Researcher attributed to differences in the rates of improvement in all motor abilities of experimental group for the control group that the proposed preliminary games are the elements of thrill and pleasure and the spirit of competition, which is reflected in the increasing tendencies and students' motivation towards the performance of those games with enthusiasm, which contributed to the growth and development of the motor abilities they have for the control group. This is consistent Amr Abou ElMagd and gamal Alnmky (2001) (7) that through the preliminary games can be balanced effect on all parts of the body, and the motor conditions that are related to preliminary games is working on use of a large number of muscle groups, which works to strengthen them.

Magdy Shawky (2000) (9) the preliminary games contribute to the development the components of fitness, and preferred to use the Games competition between groups working to increase the motivation and excitement toward practice and canceled the boredom of this part. This is consistent with a study by Mohammed Shaddad, Khalid Izzat (2012) (11), Ahmad Badawi, "2011 (2), Rania Abdel Jawad" 2008 (18), Mohamed Noah " 2005 (14), Kazlovks 1981 (22), where their findings pointed to the improvement in the level of motor abilities of the experimental group, which 
used the preliminary games, compared to the control group.

In this third hypothesis is achieved, which stipulates that There are statistically significant differences between the averages of after measurements for the experimental and control groups in the level performance of lifting up and arching skills and in favor of the experimental group.

Conclusions: The

- The proposed program of preliminary games have a positive effect on development the motor abilities of the research sample.

- The proposed program of preliminary games have a positive effect on development some of the basic skills (lifting up skill, arching skill) of the research sample.

- The proposed program of preliminary games and that has been applied to the experimental group has a positive and effective than the traditional program, which has been applied to the control group in development some of motor abilities and some basic skills (lifting up skill, arching skill)

\section{Recommendations:}

* use of the proposed program of preliminary games to improve some of motor abilities and some basic skills (lifting up skill, arching skill). * Prepare teachers training and trainers to how to design educational and training programs for improve the physical and performance skill levels for beginners in the sport of wrestling.

Innovation preliminary games suit the performance skills of professional wrestling and simulate actual situations of performance.

* Conduct similar studies on other skills in both Romania wrestling and freestyle wrestling can even improve the performance skill of the wrestlers.

* Conduct similar studies on different age groups in the wrestling sport.

\section{Arabic references:}

1. Adel Abdul Basir: Sports Training between theory and practice, el Ketal center , cairo , 1999.

\section{Ahmed Fathi Mohammed}

Hussein Badawi: the effect of the use of preliminary games to learn some basic skills in handball for pupils deaf and dumb, Master, Zagazig University, Faculty of Physical Education for Boys, 2011. 
3. Alaa eldin Aliywa Mohammed, Mohammed mersaal Hamad: physical exercise "individual -couples groups " in the form of small games, Dar Bilal center, Mansoura, 2002.

4. Ali said rehaan: Scientific Encyclopedia of wrestlerss, Faculty of Physical Education, Mansoura University, 2006.

5. Amal

Hashim

Muhammad: The effect of preliminary games on special physical abilities and Motor Sensory Perception of pupils in the basic education stage in handball, Master , Faculty of Physical Education for Girls, Helwan University, 2008.

6. Amin Anwar al-Khouly, Jamal al-Din Shafie: small games - big games -conceptual framework and educational games, Dar Arab center, Cairo, 2009.

7. Amr Abou El-Magd, and Jamal Ismail: modern tactical and recreational games to develop training programs for adults and buds in football, Cairo, the center of the book for publication, 2001.

8. Ellen Wadih Faraj: experience in gaming for kids and adults, monsha el maarf, Alexandria, 2002.
9. Magdy Ahmed Shawky: A Guide of small games, Zagazig, Azizi center, 2000. 10. Mohamed Ahmed Abdullah: Entrance in small games, Azizi center, Zagazig, 2006.

\section{1-Mohammad Hamid} Shaddad, Khalid Farid Ezzat: The effect of preliminary games program on some motor abilities and the level performance skills for buds judo, Physical Education Research Journal, Vol. 46 No. 88, Faculty of Physical Education-Boys Zagazig, Zagazig University, 2012.

\section{Mohammad Hassan}

Allawi: Encyclopedia of sports, dar el maarf, 1999.

13. Mohammed Jaber Briva, Ehab Fawzy Badawi:

Scientific Encyclopedia of Wrestling (first part) wrestling for beginners, facility knowledge, Alexandria, 2002.

\section{4-Mohamed}

Ramzy

Mohamed Noah: the effect of a training program using small games during preparation period on the effectiveness of the performance skills of the wrestling buds, Master, Faculty of Physical Education, Mansoura University, 2005.

15. Mohammad Reda Hafez Roby: training programs and 
exercises to preparation, mahi center, Alexandria, 2007.

16 - Mohamed Sobhy

Hassanein: Measurement and Evaluation in Physical Education and Sports, Part I, Dar Arab, center, 1995.

17. Mossad ali Mahmoud: Encyclopedia of Roman wrestling and free style wresling "Education - Training - Management - arbitration", Dar el kotob, Mansoura, 2003.

18. Rania Ibrahim Abdel Gawad: Effectiveness of the proposed preliminary games by using scouting method for development some of the basic skills of hockey for the students of the Faculty of Physical Education, Master, University of Alexandria, Faculty of Physical Education for Girls, 2008.
Foreign

References:

19- Byra, M .: Games, An Instructional Unit For the Middle and Secondary School, Physical Education Program, CAHPER, Journal, Ottawa 1988.

20- Dan Gobale: Coaching Wrestling Successfully, University of lowa, 1999. 21- Dennis .A \& Johnson.M.S: Wrestling Drill Book, Leisure Press, Champaign, I1 1inois, 1991.

22- Kagawkuh: Metoguka opu 3N 4Ecokozo

Bocnutahubm, 1980.

23 - Kozlobckozo B.N:

Mogtotobka, Opgtso Lutob, 1981.

24- Luttgens., K \& Hamilton.,: Kinesiology Scientific Basis Of Human Kinetics, 1997. 